\title{
FUNGSI PENGORGANISASIAN DAN EVALUASI PESERTA DIDIK
}

\author{
Oleh: Manda \\ SMAN 2 Bajo, Luwu
}

\begin{abstract}
Abstrak:
Tujuan pengorganisasian adalah agar dalam pembagian tugas dapat dilaksanakan dengan penuh tanggungjawab. Dengan pembagian tugas diharapkan setiap anggota organisasi dapat meningkatkan keterampilannya secara khusus (spesialisasi) dalam menangani tugas-tugas yang dibebankan. Apabila pengorganisasian itu dilakukan secara serampangan, tidak sesuai dengan bidang keahlian seseorang, maka tidak mustahil dapat menimbulkan kegagalan dalam penyelenggaraan pekerjaan itu. Evaluasi merupakan bagian dari kegiatan kehidupan manusia sehari-hari. Disadari atau tidak, orang sering melakukan evaluasi, baik terhadap dirinya sendiri, terhadap lingkungan sosialnya, atau lingkungan fisiknya. Evaluasi dilakukan seseorang dari hal-hal yang sangat sederhana sampai yang sangat rumit. Hal ini dilakukan supaya seseorang menentukan arah pengembangan dirinya. Evaluasi atau penilaian berarti usaha untuk mengetahui sejauh mana perubahan itu telah terjadi melalui kegiatan belajar mengajar.
\end{abstract}

\section{Kata Kunci: Fungsi, Pengorganisasian, Evaluasi, Pserta Didik}

\section{A. PENGANTAR}

Pada umumnya konsep evaluasi sebagai proses adalah: (1) mengumpulkan informasi dan (2) menggunakan standar atau kriteria dalam evaluasi (3) menarik kesimpulan, menetapkan suatu keputusan yang berguna yang dapat diaplikasikan pada semua situasi yang dihadapkan pada pimpinan organisasi. Ketiga unsur tersebut dicakup pada semua evaluasi. Semua metode kerja, kegiatan dan situasi dalam suatu organisasi dapat dievaluasi.

Evaluasi dalam konteks manajemen terutama digunakan untuk membantu memilih dan merancang kegiatan yang akan datang. Studi evaluasi dapat menilai atau menduga keadaan yang dihasilkan suatu kegiatan dalam hal ini perubahan organisasi (mencakup keluaran/output dan hasil/outcome) dan distribusi manfaat diantara berbagai kelompok sasaran, dan dapat menilai efektivitas biaya dari proyek dibanding dengan pilihan lainnya. Jika kegiatan tidak mempunyai sistem evaluasi yang efektif, bahaya akan meningkat untuk melanjutkan kegiatan yang tidak menghasilkan manfaat yang diinginkan. Evaluasi diperlukan untuk melihat kesenjangan antara "harapan dan kenyataan". Hal yang sangat dipentingkan dalam semua kegiatan evaluasi adalah kesempurnaan dan 
keakuratan data. Evaluasi pada dasarnya merupakan kajian yang merupakan kegiatan mencari faktor-faktor penyebab timbulnya permasalahan, bukan hanya sekedar gejala yang tampak dalam permukaan. Karena itu evaluasi merupakan kegiatan diagnostik, menjelaskan interpretasi hasil analisis data dan kesimpulan.

\section{B. PENGORGANISASIAN}

\section{Pengertian Pengorganisasian}

Pengorganisasian adalah suatu pola hubungan-hubungan yang melalui orangorang dibawah pengarahan menajer mengejar tujuan bersama (Dasar-Dasar Organisasi, Stoner). Pengorganisasian adalah suatu kerja sama untuk mencapai tujuan yang telah ditetapkan. (Ensiklopedia Indonesia, Jakarta 1990). Pengorganisasian adalah sebagai proses kegiatan penyusunan struktur organisasi sesuai dengan tujuan-tujuan tertentu (Kamus Kata, Source Dan Riselainer). Pengorganisasian adalah keseluruhan pengelompokan orang-orang, alat-alat, tugas, tugas,kewenangan dan tanggung jawab sedemikian rupa sehingga tercipta suatuorganisasi yang dapat digerakkan sebagai suatu kegiatan kesatuan yang telah ditetapkan (Siagian, 1983). Pengorganisasian adalah sesuatu yang digambarkan sebagai sesuatu yang tersentralisasi dan berisi tugas-tugas yang sangat terspesialisasikan (Kamus Kata Bahasa Indonesia, T. Hani Handoko). Pengorganisasian adalah merupakan kegiatan merancang dan merumuskan struktur (Kamus Lengkap Bahasa Indonesia)

\section{Tujuan Pengorganisasian}

Tujuan pengorganisasian adalah agar dalam pembagian tugas dapat dilaksanakan dengan penuh tanggungjawab. Dengan pembagian tugas diharapkan setiap anggota organisasi dapat meningkatkan keterampilannya secara khusus (spesialisasi) dalam menangani tugas-tugas yang dibebankan. Apabila pengorganisasian itu dilakukan secara serampangan, tidak sesuai dengan bidang keahlian seseorang, maka tidak mustahil dapat menimbulkan kegagalan dalam penyelenggaraan pekerjaan itu. Ada beberapa tujuan pengorganisasian, yaitu:

a) Membantu koordinasi. Memberi tugas pekerjaan kepada unit kerja secara koordinatif agar tujuan organisasi dapat melaksanakan dengan mudah dan efektif. Koordinasi 
dibutuhkan tatkala harus membagi unit kerja yang terpisah dan tidak sejenis, tetapi berada dalam satu organisasi.

b) Memperlancar pengawasan. Membantu pengawasan dengan menempatkan seorang anggota manajer yang berkompetensi dalam setiap unit organisasi. Dengan demikian sebuah unit dapat ditempatkan di dalam organisasi secara keseluruhan sedemikian rupa agar dapat mencapai sasaran kerjanya walaupun dengan lokasi yang tidak sama.

c) Maksimalisasi manfaat spesialisasi. Membantu seorang menjadi lebihahli dalam pekerjaan-pekerjaan tertentu. Spesialisasi pekerjaan dengan dasar keahlian dapat menghasilkan produk yang berkualitas tinggi, sehingga kemanfaatan produk dapat memberikan kepuasan dan memperoleh kepercayaan masyarakat pengguna.

d) Penghematan biaya. Tumbuh pertimbangan yang berkaitan dengan efisiensi. Dengan demikian pelaku organisasi akan selalu berhati-hati dalam setiap akan menambah unit kerja baru yang notabene menyangkut penambahan tenaga kerja yang relatif banyak membutuhkan biaya tambahanberupa gaji/upah. Penambahan unit kerja sebaiknya dipertimbangkan berdasarkan nilai sumbangan pekerja baru dengan tujuan untuk menekan upah buruh yang berlebihan.

e) Meningkatkan kerukunan hubungan antar manusia. Masing-masing pekerja antar unit kerja dapat bekerja saling melengkapi, mengurangi kejenuhan, menumbuhkan rasa saling membutuhkan, mengurangi pendekatan materialistis. Untuk ini pihak manajer harus mampu mengadakan pendekatan sosial dengan penanaman rasa solidaritas dan berusaha menampung serta menyelesaikan berbagai perbedaan yang bersifat individual.

\section{Unsur-Unsur Organisasi}

a. Sebagai wadah atau tempat bekerja sama.

b. Sebagai proses kerja sama antara dua orang atau lebih.

C. Adanya tugas atau kedudukan yang jelas.

d. Mempunyai tujuan tertentu.

\section{Pengertian Pembelajaran}

Pembelajaran adalah suatu proses yang dilakukan oleh individu untuk memperoleh suatu perubahan perilaku yang baru secara keseluruhan, sebagai hasil dari 
pengalaman individu itu sendiri dalam interaksi dengan lingkungannya. Beberapa prinsip yang menjadi landasan pengertian tersebut ialah :

a) Pembelajaran sebagai suatu usaha memperoleh perubahan perilaku. Prinsip ini bermakna bahwa prosees pembelajaran itu ialah adanya perubahan perilaku dalam diri individu.

b) Hasil pembelajaran ditandai dengan perubahan perilaku secara keseluruhan.

c) Pembelajaran merupakan suatu proses. Prinsip ini mengandung makna bahwa pembelajaran merupakan suatu aktifitas yang berkesinambungan.

d) Proses pembelajaran terjadi karena adanya sesuatu yang mendorong dan ada suatu tujuan yang ingin dicapai.

e) Pembelajaran merupakan suatu pengalaman.

\section{STRATEGI PENGORGANISASIAN PEMBELAJARAN}

Pengorganisasian pembelajaran memiliki peranan penting dalam kegiatan pembelajaran khususnya dalam menyusun skema tahapan kegiatan (alur kegiatan pembelajaran) perngembangan organisasi melalui visi dan misi tidak terbatas membentuk strategi yang strategis melainkan bagaimana kita harus dapat memadukan sebuah keterampilan mengelola strategi pengorganisasian pembelajaaraan yang terpadu, seperti :

1. Waktu merupakan nilai efisiensi ( tolak ukur ) dimana suatu pengorganisasian terjadi karena beberapa literatur pelaksanaan dan evaluasi kegiatan strategi pengorganisasian pembelajaran.

2. Tempat merupakan landasan awal dalam proses pengembangan organisasi dibentuk (dikemas) sesuai dengan analisis kebutuhan di tempat dimana pengorganisasian pembelajaran tersebut dilaksanakan.

3. Tujuan pengorganisasian pembelajaran harus operasional dan konkret yaitu memiliki tujuan pembelajaran khusus, tujuan pembelajaran umum, tujuan kurikuler, tujuan nasional, sampai pada tujuan yang bersifat universal.

Strategi pengorganisasian pembelajaran disebut oleh Reigeluth, Bunderson, dan Merrill (1977) sebagai structural strategy, yang mengacu kepada cara untuk membuat urutan (sequencing) dan mensintesis(synthesizing) fakta-fakta, konsep-konsep, prosedur, atau prinsip-prinsip yang berkaitan. Sequencing mengacu kepada pembuatan urutan 
penyajian isi bidang studi dan synthesizing mengacu kepada upaya untuk menunjukkan kepada si-pembelajar keterkaitan antar isi bidang studi itu.

Pengorganisasian pembelajaran secara khusus, merupakan fase yang amat penting dalam rancangan pembelajaran. Synthesizing akan membuat topik-topik dalam suatu bidang studi menjadi lebih bermakna bagi peserta didik (Ausubel,1968) yaitu dengan menunjukkan bagaimana topic-topik itu terkait dengan keseluruhan isi bidang studi. Sequencing atau penataan urutan, amat diperlukan dalam pembuatan sintesis. Strategi pengorganisasian pembelajaranterbagi menjadi Strategi Makro dan Strategi Mikro. Strategi pengorganisasian makro diacukan untuk menata keseluruhan isi bidang studi, strategi pengorganisasian mikro diacukan untuk menata sajian suatu konsep, atau prinsip, atau prosedur.

\section{PENGORGANISASIAN PEMBELAJARAN (URUTAN PEMBELAJARAN)}

Kini sampai pada inti kajian yaitu mendeskripsikan cara yang diperkenalkan Gagne dalam mengorganisasikan urutan pembelajaran. Pertimbangan terpenting dalam membuat urutan pembelajaran adalah ada tidaknya prasyarat untuk suatu kapabilitas, dan apakah peserta didik telah memiliki prasyarat belajar itu.

1. Model Taba : Pembentukan Konsep

Taba (1980) memperkenalkan strategi pengorganisasian pembelajaran tingkat mikro, khusus untuk belajar konsep dengan pendekatan induktif. Strategi yang diciptakannya terdiri dari tiga tahapan sejalan dengan tiga tingkatan proses berpikir yang dikemukakannya. Ketiga tingkatan proses berpikir itu adalah: (1) pembentukan konsep, (2) intepretasi, dan (3) aplikasi prinsip.

\section{Model Bruner: Pemahaman Konsep}

Pembentukan konsep dan pemahaman konsep merupakan dua kegiatan mengkategorikan yang berbeda yang menuntut proses berpikir yang berbeda pula. Seluruh kegiatan mengkategori meliputi mengidentifikasi dan menempatkan contohcontoh ke dalam kelas dengan menggunakan dasar criteria tertentu. Bruner (1980) memandang bahwa suatu konsep memilki lima unsur dan seseorang dikatakan memahami suatu konsep apabila ia mengetahui semua unsur dari konsep itu. Kelima unsur tersebut 
adalah (1) Nama; (2) Contoh-contoh; (3) Karakteristik, baik yang pokok maupun tidak; (4) Rentangan karakteristik, dan (5) Kaidah.

\section{E. FAKTOR YANG MEMPENGARUHI PERWUJUDAN PENGORGANISASIAN KELAS}

Pengorganisasian pembelajaran juga mempengaruhi pengorganisasian di dalam kelas. Adapun faktor yang mempengaruhi perwujudan pengorganisasian kelas, yaitu :

a. Kurikulum

Kurikulum kaitannya dengan pengorganisasian kelas haruslah di rancang sebagai jumlah pengalaman edukatif yang menjadi tanggung jawab sekolah dalam membantu anak-anak mencapai tujuan pendidikannya, yang diselenggarakan secara berencana dan terarah serta terorganisir, karena kegiatan kelas bukan sekedar dipusatkan pada penyampaian sejumlah materi pelajaran atau pengetahuan yang bersifat intelektualistik, akan tetapi juga memperhatikan aspek pembentukan pribadi, baik sebagai makhluk individual dan makhluk social maupun sebagai makhluk yang bermoral. Oleh karena itu disamping aspek materi pengetahuan diperlukan program kelas untuk memenuhi perbedaan minat bakat dan kemampuan murid. Program tersebut dapat dilakukan melalui aspek-aspek kependidikan dibidang kesenian termasuk kesejahteraan keluarga, tekhnik, olahraga, kepramukaan dan kesehatan pada kelas-kelas terakhir sekolah menengah tingkat atas programnya harus dirancangkan untuk membantu anak-anak mewujudkan diri dalam memasuki masyarakat sebagai orang dewasa. Program itu antara lain harus diarahkan untuk memeberikan keterampilan tertentu guna memasuki lapangan kerja tingkat menengah atas disamping program untuk memeprsiapkan para remaja agar menjadi warga negara yang memahami dan mampu menjalankan hak dan kewajibannya.

b. Gedung dan Sarana Kelas atau Sekolah

Perencanaan dalam membangun sebuah gedung untuk sebuah sekolah berkenaan dengan jumlah dan luas setiap ruangan, letak dan dekorasinya yang harus disesuaikan dengan kurikulum yang dipergunakan. Akan tetapi karena kurikulum selalu dapat berubah. Sedang ruangan atau gedung bersifat permanen, maka diperlukan kreativitas dalam mengatur pendayagunaan ruang / gedung yang bersedia berdasarkan kurikulum yang dipergunakan. Dalam konteks ini kepandaian guru dalam pengorganisasian kelas sangat dibutuhkan 
c. Guru

Hadari Nawawi menyatakan guru adalah orang yang bekerja dalam bidang pendidikan dan pengajaran yang bertanggung jawab dalam memebnatu anak dalam mencapai kedewasaan masing-masing. Guru dalam pengertian tersebut bukan sekedar berdiri didepan kelas untuk menyampaikan materi atau pengetahuan tertentu, akan tetapi dalam keanggotaan masyarakat yang harus aktif dan berjiwa bebas serta kreatif dalam mengarahkan perkembangan anak didiknya untuk menjadi anggota masyarakat sebagai orang dewasa. Guru juga harus bisa juga menciptakan suasana dalam kelas agar terjadi interaksi belajar mengajar yang dapat memotivasi sesuai untuk belajar dengan baik dan sungguh-sungguh. Berdasarkan uraian-uraian diatas jelas bahwa jabatan guru sebagai suatu profesi tidak saja mulia, karena berhubungan langsung dengan masalah pendewasaan anak-anak, akan tetapi juga merupakan tugas yang cukup berat. Tugas yang mulia dan hanya dapat diwujudkan oleh orang-orang yang memiliki kecintaan terhadap pekerjaan mendidik.

d. Murid

Murid sebagai unsur kelas memiliki perasaan kebersamaan (Sense Of kolektive) merupakan kondisi yang sangat penting artinya bagi terciptanya kelas yang dinamis. Oleh karena itu, setiap murid harus memiliki perasaan diterima (Sense of membershif) terhadap kelasnya agar mampu ikut serta dalam kegiatan kelas. Perasaan inilah yang akan menumbuhkan rasa tanggung jawab (Sense of respsibility) terhadap kelasnya. Sikap ini akan tumbuh dengan baik apabila dilakukan tindakan-tindakan pengorganisasian kelas sebagai berikut :

1) Setiap murid dilibatkan dalam proses perencanaan dan pelaksanaan kegiatan kelas, guru hanya sekedar memberi petunjuk dan bimbingan agar program atau kegiatannya sejalan dengan kurikulum.

2) Murid diberi kesempatan dalam pembagian tugas-tugas untuk kepentingan kelas.

3) Bila guru atau wali kelas berhalangan, bagi dan serahkanlah kepercayaan berupa tanggung jawab mengatur rumah tangga dan disiplin kealas diantar murid.

4) Motivasi agar setiap murid selalu bersedia mengatur kelasnya melalui kegiatan rutin, misalnya membersihkan kelas, papan tulis dan lain-lain.

5) Kembangkanlah kesediaan bekerjasama dalam setiap kegiatan. 
6) Susunlah bersama murid tata tertib dan disiplin kelas serta bentuklah pengurus kelas yang bekerja selama 1 tahun ajaran.

7) Doronglah agar murid secara terus menerus ikut memikirkan kegiatan kelas dan berani mengusulkannya untuk dilaksanakan bersama didalam atau diluar kelas.

e. Dinamika Kelas

Kelas adalah kelompok sosial yang dinamis yang harus dipergunakan oleh setiap wali atau guru kelas untuk kepentingan murid dalam proses kependidikannya. Dinamika kelas pada dasarnya berarti kondisi kelas yang diliputi dorongan untuk aktif secara terarah yang dikembangkan melalui kretifitas dan inisiatif murid sebagai suatu kelompok, untuk itu setiap wali atau guru kelas harus berusaha menyalurkan berbagai saran, pendapat, gagasan, keterampilan, potensi dan energi yang dimiliki murid menjadi kegiatan-kegiatan yang berguna. Dengan demikian kelas tidak akan berlangsung secara statis, rutin dan membosankan. Dinamika kelas ini dipengaruhi berbagai komponen yang sangat disyaratkan dalam pengorganisasian kelas.

\section{F. EVALUASI}

Menurut Wand dan Brown (dalam Syaiful Bahri Djamarah dan aswan zain, 2002;57), evaluasi adalah suatu tindakan atau proses untuk menentukan nilai dari sesuati. evaluasi hasil belajar peserta didik berarti kegiatan menilai proses dan hasil belajar siawa baik yang berupa kegian kurikuler, ko-kurikuler, maupun ekstra-kurikuler. Penilaian hasil belajar bertujuan untuk melihat kemajuan hasil belajar peserta didik dalam hal penguasaan materi pengajaran yang telah dipelajari sesuai dengan tujuan-tujuan yang telah ditetapkan. 1. Tujuan umum dari evaluasi peserta didik adalah:

a. Mengumpulkan data-data yang membuktikan taraf kemajuan peserta didik dalam mencapai tujuan yang diharapkan.

b. Memungkinkan pendidik/guru menilai kativitas/pengalam yang didapat.

c. Menilai metode mengajar yang digunakan.

2. Tujuan khusus dari evaluasi peserta didik adalah:

a. Merangsang kegiatan peserta didik

b. Menemukan sebab-sebab kemajuan atau kegiatan belajar peserta didik. 
c. Memberikan bimbingan yang sesuai dengan kebutuhan perkembangan dan bakat siswa yang bersangkutan.

d. Untuk memperbaiki mutu pembelajaran/cara belajar dan metode belajar.

Berdasarkan tujuan penilaian hasil belajar tersebut ada beberapa fungsi penilaian yang dapat dikemukakan antara lain:

\section{Fungsi Selektif}

Dengan mengadakan evaluasi, guru mempunyai cara untuk mengadakan seleksi atau penilaian terhadap peserta didiknya. Evaluasai dalam hal ini bertujuan untuk: memilih peserta didik yang dapat diterima di sekolah tertentu, memilih peserta didik yang dapat naik kelas atau tingkat berikutnya, memilih siswa yang seharusnya mendapat beasiswa, memilih siswa yang seharusnya berhak meninggalkan sekolah, dan sebagainya.

\section{Fungsi diagnostic}

Apabila alat yang digunakan dalam evaluasi cukup memnuhi persyaratan, dengan melihat hasilnya, guru akan dapat mengetahui kelemahan peserta didik, sehingga lebih muadh untuk mencari cara mengatasinya.

\section{Fungsi Penempatan}

Pendekatan yang lebih bersifat melayani perbedaan kemampuan peserta didik adalah pengajaran secara kelompok. Untuk dapat menentukan dengan pasti di kelompok mana seorang peserta didik harus ditempatkan.

\section{Fungsi menukur keberhasilan program}

Evaluasi ini dimaksudkan untuk mengetahui sejauh mana suatu program berhasil diterapkan.

Secara garis besar ada dua macam alat evaluasi, yaitu tes dan non tes. Dalam penggunaan alat evaluasi yang berupa tes, hendaknya guru membiasakan diri tidak hanya menggunakan tes subyektif saja tetapi juga diimbangi dengan tes uraian. Tes adalah penilaian yang komperhensif terhadap seseorang individu atau keseluruhan usaha evaluasi program.

Dalam suatu kelas, tes mempunyai fungsi ganda, yaitu untuk mengukur keberhasilan peserta didik dan untuk mengukur keberhasilan program pengajaran. Ditinjau dari segi kegunaan untuk mengukur keberhasilan peserta didik, ada juga tiga jenis tes, yaitu: 
1. Tes diagnostic

Tes diagnostic adalah tes yang digunakan untuk mengetahui kelemahan-kelamahan peserta didik sehingga berdasarkan kelemahan tersebut dapat dilakukan pemberian perlakuan yang tepat. Kedudukan diagnosis adalah dalam menemukan letak kesulitan belajar peserta didik dan menentukan kemungkinan cara mengatasinya dengan memperhitungkan faktor-faktor yang mempengaruhi kegiatan belajar.

\section{Tes formatif}

Tes formatif atau evaliasi formatif dimaksudkan untuk mengetahui sejauh mana peserta didik telah terbentuk setelah mengikuti suatu program tertentu. Jenis penilaian ini juga berfungsi untuk memperbaiki proses belajar mengajar.

\section{Tes sumatif}

Tes sumatif atau evaluasi sumatif dilaksanakan setelah berakhir pemberian sekelompok program atau pokok bahasan. Jenis penilaian ini berfungsi untuk menentukan angka kemajuan hasil belajar peserta didik.

Hasil evaluasi terhadap peserta didik tersebut selanjutnya ditindaklanjuti dengan memberikan umpan balik. Ada dua kegiatan dalam menindaklanjuti hasil penilaian peserta didik, antara lain sebagai berikut.

\section{Program Remidial}

Belajar tuntas merupakan kriteria keberhasilan kegiatan belajar-mengajar. Maksud utama konsep belajar tuntas adalah upaya agar dikuasainya bahan secara tuntas oleh sekelompok peserta didik yang sedang mempelajari bahan tertentu secara tuntas. Tingkat ketuntasan ini bermacam-macam dan merupakan persyaratan (kriteria) minimum yang harus dikuasai peserta didik. Batas minimum ini kadang-kadang dijadikan dasar kelulusan bagi peserta didik yang menepuh bahan tersebut. Biasanya dipersyaratkan penguasaan bahan pelajaran bergerak antara $75 \%$ sampai $90 \%$.

Pengajaran remedial mempunyai arti terapeutik, maksudnya dalam proses pengajaran remedial secara langsung maupun tidak langsung juga menyembuhkan beberapa gangguan atau hambatan yang berkaitan dengan kualitas belajar. Pengajaran remedial adalah suatu bentuk khusus pengajaran yang ditujukan untuk menyembuhkan atau memperbaiki sebagian atau keseluruhan kesulitan belajar yang dihadapi oleh peserta didik. Perbaikan diarahkan kepada pencapaian hasil belajar yang optimal sesuai dengan 
kemampuan masing-masing melalui perbaikan keseluruhan proses belajar mengajar dan keseluruhan kepribadian peserta didik.

Sasaran akhir kegiatan remedial identik dengan pengajaran biasa (pada umumnya) yaitu membantu setiap peserta didik dalam batas-batas normalitas tertentu agar dapat mengembangkan diri seoptimal mungkin sehingga dapat mencapai tingkat penguasaan atau ketuntasan tertentu, sekurang-kurangnyasesuai dengan batas kriteria keberhasilan yang dapat diterima. Secara empiric sasaran strategis tersebut tidak selamanya dapat tercapai dengan pendekatan sistem pengajaran secara konvensional, sehingga perlu dicari upaya pendekatan strategis lainnya. Ada dua strategi yang bisa dilakukan dalam pendekatan remedial, yaitu:

\section{a. Strategi dan pendekatan pengajaran yang bersifat kuartif}

Tindakan ini dapat dikatakan kuartif apabila dilakukan setelah selesai program pembelajaran utama diselenggarakan. Hal ini dilakukan atas dasar bahwa ada seseorang atau beberapa orang atau keseluruhan peserta didik dapat dipandang tidak mampu menyelesaikan program proses belajar-mengajar yang bersangkutan secara sempurna sesuai dengan kriteria keberhasilan yang telah ditetapkan.

b. Strategi dan pendekatan pengajaran yang bersifat preventif

Teknik layanan pengajaran yang digunakan adalah:

1) Layanan kepada kelompok belajar homogeny

2) Layanan pengajaran individual

3) Layanan pengajaran secara kelompok dengan dilengkapi kelas khusu remedial dan pengayaan

C. Strategi pendekatan pengajaran yang berdifat pengembangan

Dalam pengajaran remedial diperlukan adanya pengorganisasian proses belajar mengajar yang siatematis dalam bentuk sistem pengajaran berprogram, sistem pengajaran modul, dan sebagainya. Sasaran utama dari strategi ini adalah agar peserta didik dapat segera mengatasi hambatan atau kesulitan yang mungkin dialaminya selama melaksanakan kegiatan belajar mengajar. 


\section{Program Pengayaan}

Kegiatan pengayaan adalah kegiatan yang diberikan kepada peserta didik kelompok cepat seghingga peserta didik tersebut menjadi lebih kaya pengetahuan dan ketrampilannya atau lebih mendalami bahan pengajaran yang sedang mereka pelajari. Tujuan dari kegiatan pengayaan adalah agar peserta didik yang sudah menguasai bahan lebih dahulu dari teman-temannya tidak brhenti perkembangannya, dengan mengisi waktu kelebihaanya dengan melakukan kegiatan lain. Strategi kegiatan pengayaan dapat dilakukan dengan dua cara, yaitu:

a. Kegiatan pengayaan yang berhubungan dengan topik modul pokok

b. Kegiatan pengayaan yang tidak berhubungan dengan topik modul pokok

Kegiatan pengayaan untuk dapat efektif mencapai tujuan, maka perlu diadakan kegaiatan penilaian, melalui dua cara yaiyu:

a. Digabungkan dengan nilai modul pokok, dihitung dalam satuan kredit atau bobot tertentu

b. Dipisahkan dengan nilai pokok sehingga terdapat dua nilai.

\section{G. PENUTUP}

Pengorganisasian adalah suatu pola hubungan-hubungan yang melalui orangorang dibawah pengarahan menajer mengejar tujuan bersama (Dasar-Dasar Organisasi, Stoner). Pengorganisasian adalah suatu kerja sama untuk mencapai tujuan yang telah ditetapkan. (Ensiklopedia Indonesia, Jakarta 1990). Pengorganisasian adalah sebagai proses kegiatan penyusunan struktur organisasi sesuai dengan tujuan-tujuan tertentu (Kamus Kata, Source Dan Riselainer). Pengorganisasian adalah keseluruhan pengelompokan orang-orang, alat-alat, tugas, tugas,kewenangan dan tanggung jawab sedemikian rupa sehingga tercipta suatuorganisasi yang dapat digerakkan sebagai suatu kegiatan kesatuan yang telah ditetapkan (Siagian, 1983). Pengorganisasian adalah sesuatu yang digambarkan sebagai sesuatu yang tersentralisasi dan berisi tugas-tugas yang sangat terspesialisasikan (Kamus Kata Bahasa Indonesia, T. Hani Handoko). Pengorganisasian adalah merupakan kegiatan merancang dan merumuskan struktur (Kamus Lengkap Bahasa Indonesia). 
Proses ahir dari sebuah kegiatan pembelajaran adalah kita melakukan evaluasi.Evaluasi mutlak dilakukan untuk menentukan hasil keberhasilan dari proses ataupun metode yang dilaksanakan. Banyak diatara kita sebagai calon pendidik yang belum mengerti arti evaluasi yang sesungguhnya,sehingga dalam melakukan evaluasi belum memakai teknik-teknik evaluasi yang distandarkan dengan kriteria-kriteria yang seharusnya dikerjakan.

\section{DAFTAR PUSTAKA}

Madya, Wahyu. 2011. Pendekatan Pembelajaran (Online),http://kerorowahyu.blogspot.com/2011/10/pendekatanpembelajaran.html, diakses 4 Oktober 2016.

Notako. 2013.

Pendekatan

Pembelajaran

(Online),https://notako.wordpress.com/2013/10/19/makalah-pendekatanpembelajaran-2I , diakses 4 Oktober 2016

Nuryani, Cucu. 2011. Pembelajaran Individual dan Pembelajaran Kelompok, (Online), (cucunuryani.blogspot.com/2011/08/pembelajaran-individual-dan.html. Jumat, 12 Agustus 2011), diakses 7 Oktober 2016.

Saputra, Trio $\quad$ Redo. 2012. Pengorganisasian Siswa (Online),http://tirtanizertrs.blogspot.com/2012/11/pengorganisasian-siswa.html , diakses 7 Oktober 2016

Suhardan, Dadang, dkk. 2009. Manajemen Pendidikan. Bandung: PT. Albeta.

Stiava Rizema, 2012, Desain Evaluasi Belajar Berbasis Kinerja, Jogjakarta: Diva Press.

Slameto, 1988, Evaluasi Pendidikan, Jakarta: Bina Aksara. 